OPEN ACCESS

Edited by:

Shang Gao,

The University of Melbourne, Australia

Reviewed by:

Xianbo Zhao,

Central Queensland

University, Australia

Dong Zhao,

Michigan State University

United States

*Correspondence:

Safi Ullah

safi@seu.edu.cn

Xiaopeng Deng

dxp@seu.edu.cn

Specialty section:

This article was submitted to Construction Management,

a section of the journal

Frontiers in Built Environment

Received: 30 May 2019 Accepted: 05 August 2019

Published: 20 August 2019

Citation:

Ullah S, Deng X and Chang T (2019)

Forming Mechanism of Political Risks in International Construction Projects:

From the Perspective of Chinese

Contractors.

Front. Built Environ. 5:101. doi: 10.3389/fbuil.2019.00101

\section{Forming Mechanism of Political Risks in International Construction Projects: From the Perspective of Chinese Contractors}

\author{
Safi Ullah*, Xiaopeng Deng * and Tengyuan Chang \\ School of Civil Engineering, Southeast University, Nanjing, China
}

The performance is analyzed from the perspective of the characteristics of overseas business of Chinese contractors and political risks. Based on the results of this research project, the funds and pricing model of Chinese Contractors Overseas Projects were further analyzed, as well as their ability to withstand political risks and coping strategies. The purpose of this study was to study the statistical analysis of risks in design systems and international activities within the framework of international construction projects. This research is based on one belt and one road. The questionnaire was distributed to 100 Chinese international contractors in the form of emails. Of the 100 contractors, 50 are in the top 225 of the 2017 ENR. Research was based on the projects, and for each project only a single questionnaire was filled in, for a total of 370 responses, and a recovery rate was $37 \%$. Three hundred seventy respondents were from 46 Chinese international contractors, of which 28 (60.87\%) are from top ENR225 enterprises and 18 (39.13\%) are from other enterprises. This survey reflects the general situation of political risks of Chinese contractors in overseas project management. Generally speaking, Chinese contractors are facing higher political risks, and they do not attach enough importance to political risks, and their ability to deal with political risks. The study provides useful guidance on how to manage the political risks that international contractors create in this emerging market.

\section{Keywords: international project, construction, political risk, Chinese contractor, questionnaire survey}

\section{INTRODUCTION}

International construction operations are prone to global influences as they create political, financial, cultural and legal risks (Gunhan and Arditi, 2005). The international political and economic situation has had a great impact on the international construction industry, as shown in Figure 1. The financial crisis, local wars or upheavals, and the global war on terror have all changed the course of the international engineering market to a great extent. Under the influence of these events, international contractors will also face extremely serious political risks.

China has the widest range of cooperation in the field of construction, where Five Central Asian Countries are the important economic and business partners (Kuchins et al., 2015), Under the guidance of the "going out" strategy, China's international contractors have made leap-step developments in their foreign contracted engineering business, but at the same time, the political 


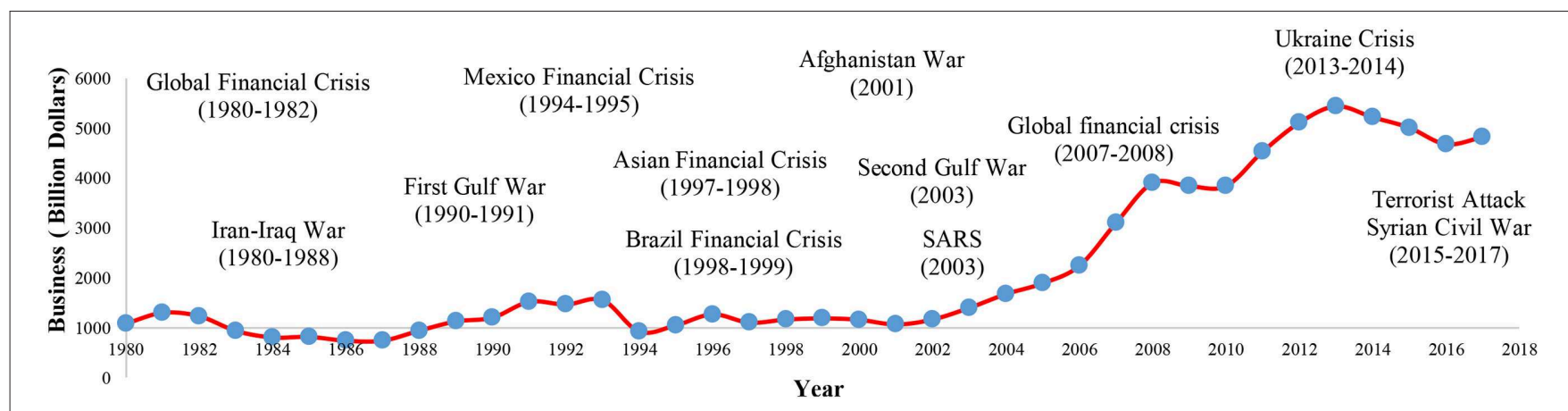

FIGURE 1 | Global 225/250 largest contractor turnover graph and international events, 1980-2017.

risks in the international market have also caused catastrophic losses to Chinese contractors. As in 1998, after the Chinese riots in Indonesia, ethnic contradictions and religious conflicts were intertwined, leading to social unrest and political chaos. After entering the year 2000, as more Chinese contractors entered into the international engineering market, the political risk incidents they faced continued unabated.

These cases warn that China's international engineering contracting industry is faced with great political risks. Unfortunately, political risk has not attracted enough attention, and many Chinese contractors have developed risk management plans overseas, even without political risk considerations. The "Industry-oriented catalog for foreign investment country" is issued by the Chinese government every year to encourage and guide Chinese enterprises to carry out targeted foreign investment. Over the past few years, many debates have been held in the field of international trading, where political risks were recognized as risky political actions (Howell and Chaddick, 1994; De Mortanges and Allers, 1996; Zhuang et al., 1998), Political risk assessments of the countries concerned are almost never involved. Therefore, it is imperative to make an effective assessment of the political risks of international engineering projects and make scientific decisions. Much of the available literature on political risks focuses on the political risks associated with Foreign Direct Investment (FDI), Multinational Enterprises (MNEs) and International Joint Ventures (MIF) in national or Industrial level of international joint operations, identification, estimation, consideration and management (Xiaopeng and Pheng, 2013).

Political risk has always been an unavoidable and hot issue in the international expansion of multinational enterprises (Kesternich and Schnitzer, 2010). Increased political risk has been proven to reduce ownership and leverage depending on the nature of political risk. Other variables, include internationalization (Al Khattab et al., 2007), inferential awareness (Frynas and Mellahi, 2003), and misbehavior of contractors (Fan and Fox, 2009), moreover, previous investigations were also considered. Political risks arise from political events (such as revolutions, coups, civil wars, etc.), social events (terrorist attacks, protests, etc.), government actions (such as corruption, legal changes and policy regulations), and the actions of some powerful social organizations (such as strikes by trade unions, protests by environmental protection organizations), which lead to changes in the operating environment of international engineering contractors and political risks. Political risks are unnecessary changes and unforeseen significance for political events in international companies (Robock and Simmonds, 1973; Henisz, 2000) and there is a serious threat to foreign operations of international contractors (Ashley and Bonner, 1987; Xiaopeng and Pheng, 2013). Uncertainty has a great potential impact and adverse consequences on the profits of enterprises. In the post-crisis era, the global economic recession has accelerated the trend of state intervention in the market, as well as the interweaving of traditional factors and non-traditional factors, making political risks present a high-frequency, destructive and complex development trend. The political risks faced by multinational companies are broader and more complex than before, and their forms are more diverse. From nationalization, civil strife in war, extreme acts of terrorist attacks, to more moderate government intervention (such as policy and law changes, encroachment levy), and public opposition caused by environmental problems. Various political risks spread at a faster speed, through diversified channels, in a larger time and space range, in a non-linear, chain, cross-temporal and spatial coupling manner.

\section{LITERATURE REVIEW}

Political risk management is a popular topic in international entrepreneurship (e.g., foreign direct investment, trade in goods and international joint ventures). A number of strategies have been adopted to address political risks, such as investing only in safe havens, increasing the required returns, adapting to a specific business environment, sharing risks with other companies, improving the negotiating mandates, passing risks to insurance companies, reducing weaknesses, investing in risk diversification in a number of countries, increasing competitiveness, and implementing localization and inclusiveness strategies.

Existing policy risk studies mainly concern on international common business (Deng and Low, 2013). International engineering projects have the characteristics of large scale, long cycle and region, and their political risks embody distinct industry characteristics. External political risks are combined 
with various risks inherent in the project itself (Laruelle and Peyrouse, 2015). At the same time, the business of Chinese contractors is mainly concentrated in underdeveloped areas, and the political risks they face also reflect distinct Chinese characteristics, such as the combination of "China factor" and regional conflicts, international terrorism, religious extremism (such as Pakistan, Afghanistan, Sudan, Myanmar, etc.); and the combination of "China factor" and local "anti-China" sentiment (such as Vietnam, India, Philippines, Indonesia, etc.). The opaque relationship between the Chinese government and stateowned enterprises has made the background of state-owned enterprises pan-politicized; differences in ideology, cultural traditions, religious beliefs, and government involvement in Chinese enterprises state-owned ownership and political purposes making China International contractors face more institutional barriers and more complex political risks. Several studies were carried out to revise political risks in Central Asian countries (Denisova-Schmidt et al., 2014; Kuchins et al., 2015; Laruelle and Peyrouse, 2015; Mazhikeyev et al., 2015).

Vulnerability reflects the vulnerability of the system under external threats, it is an integral feature of the system, which does not rely on external threats, but is used by external threats. Most studies have focused on factors such as the relative right to negotiate between companies and government (Kobrin, 1987), entry mode-choice (Alon and Martin, 1998; Iankova and Katz, 2003; Chen, 2008), custom distance (Keillor et al., 2009), internationalization (Agarwal and Feils, 2007), localization (Han et al., 2007), and so on.

As shown in Figure 2, the formation of political risk in international engineering projects has its own specific laws: on the one hand, external environmental factors lead to the breakdown of the balance of the political, social and economic systems which leads to possible threats that affect the entire construction industry or directly to individual projects; some characteristics of the design system itself make it vulnerable. External threats and the use of vulnerability in a project to share an international project pose political risks. It can directly affect the nation-building sector by expanding development rules and mandatory relationships that indirectly affect enterprises by creating difficult conditions (Iankova and Katz, 2003).

\section{METHODOLOGY}

Most political events depend on the company and on the projects (Kobrin, 1982). Weak institutions whose judicial bodies are questionable may lead to a loss of public confidence in the justice system (Ashley and Bonner, 1987; Farrell and Knight, 2003). To obtain a broader understanding feature of the overseas project system of Chinese contractors and the advantages and disadvantages of the project system under political risk, a total of 1000 questionnaires were issued to acquire the business situation of China's international contractors. The characteristics of the project, the political risk events encountered the response measures to the risk events, information on the degree of consistency between the host country's construction industry and national economic objectives, as well as industry maturity were collected. The questionnaire was distributed to 100 Chinese international contractors in the form of emails. Of the 100 contractors, 50 are in the top 225 of the 2017 ENR. Researches was based on the projects, and for each project only a single questionnaire was filled in a questionnaire, for a total of 370 responses, and a recovery rate of $37 \%$.

Table 1 shows the information of 370 respondents. Three hundred seventy respondents were from 46 Chinese international contractors, of which $28(60.87 \%)$ were from top ENR225 enterprises and 18 (39.13\%) were from other enterprises. In terms of the nature of work, $19.73 \%$ of the respondents were engaged in senior management in enterprises, $62.43 \%$ were engaged in project management, and $17.84 \%$ were project engineers. In terms of working life, $50.27 \%$ of contestants had more than six (06) years of international contracting experience. This provides the basic guarantee for the reliability of the case from the source.

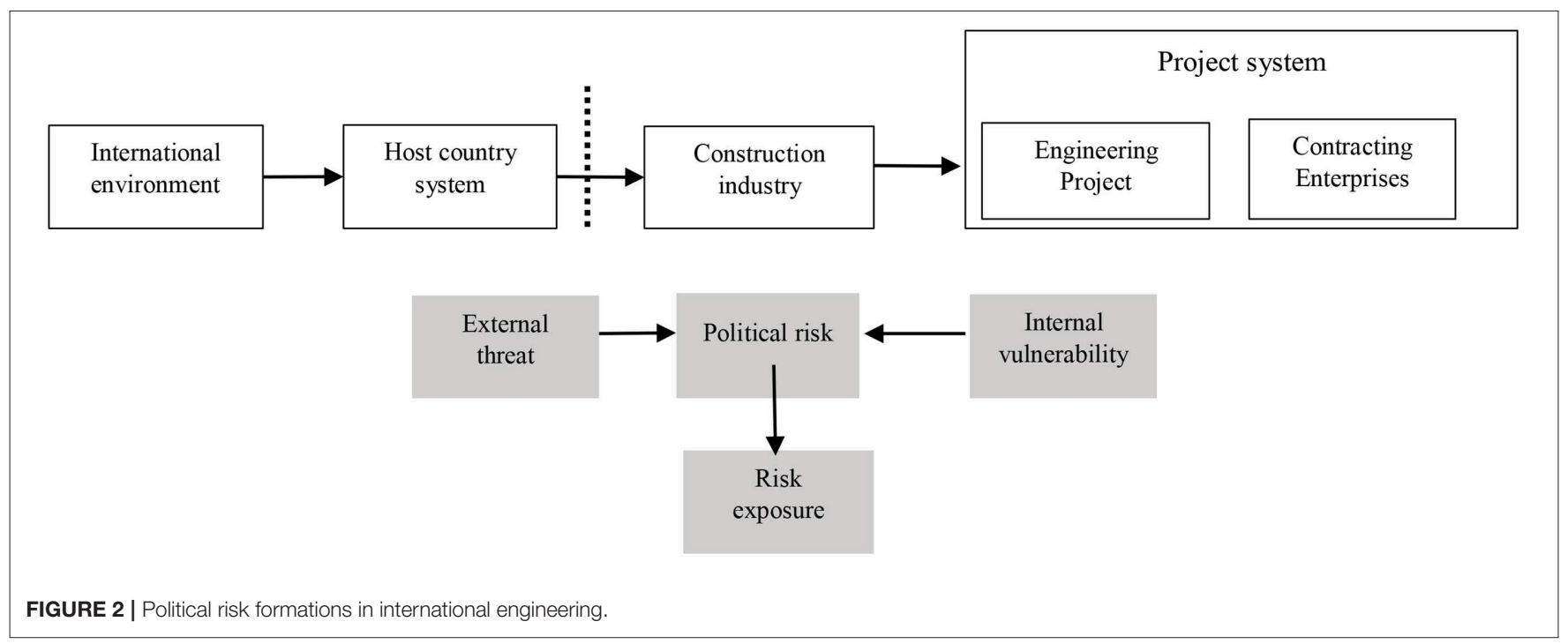


TABLE 1 | Statistical table of basic features of questionnaire samples.

\begin{tabular}{|c|c|c|c|c|}
\hline \multicolumn{3}{|c|}{ Project } & \multirow{2}{*}{$\begin{array}{c}\begin{array}{c}\text { Number } \\
\text { (N) }\end{array} \\
28\end{array}$} & \multirow{2}{*}{$\begin{array}{c}\begin{array}{c}\text { Proportion } \\
\text { (\%) }\end{array} \\
60.87 \%\end{array}$} \\
\hline Company & & ENR 250 (225) & & \\
\hline & & Others & 18 & $39.13 \%$ \\
\hline \multirow[t]{7}{*}{$\begin{array}{l}\text { Respondents } \\
(N=370)\end{array}$} & Job position & $\begin{array}{l}\text { Senior } \\
\text { management }\end{array}$ & 73 & $19.73 \%$ \\
\hline & & $\begin{array}{l}\text { Project } \\
\text { management }\end{array}$ & 231 & $62.43 \%$ \\
\hline & & $\begin{array}{l}\text { Project } \\
\text { engineer }\end{array}$ & 66 & $17.84 \%$ \\
\hline & $\begin{array}{l}\text { Working } \\
\text { service }\end{array}$ & $<2$ Years & 57 & $15.41 \%$ \\
\hline & & 3-5Years & 70 & $18.91 \%$ \\
\hline & & 6-10Years & 186 & $50.27 \%$ \\
\hline & & $>10$ Years & 57 & $15.41 \%$ \\
\hline
\end{tabular}

\section{Proportion $\begin{gathered}\text { Middle } \\ \text { East, }\end{gathered}$}

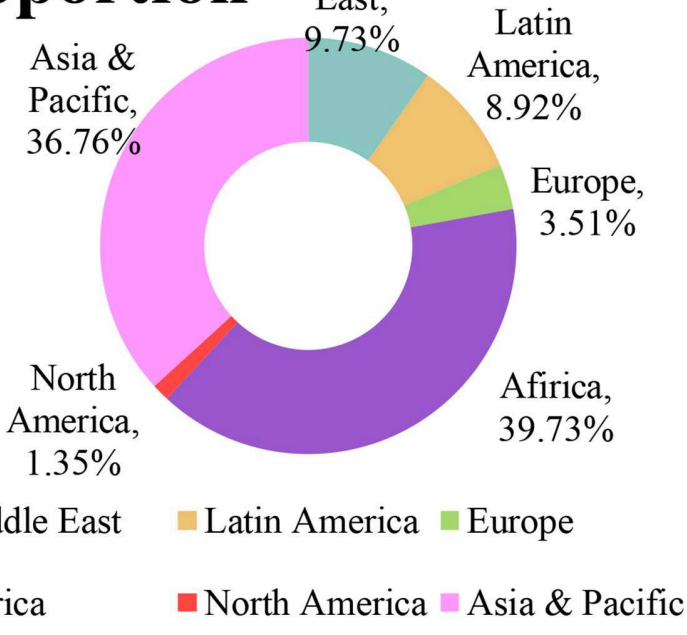

FIGURE 3 | Distribution of research projects.

The project information collected can be a very good indicator for the overseas business characteristics of Chinese contractors. The distribution of project locations is shown in Figure 3. Projects in the Asia-Pacific region accounted for $36.76 \%$, in Africa 39.73\%, in the Middle East 9.73\%, and in Latin America 8.92\%. Projects from Asia, Africa and Latin America (including the Middle East) accounted for $95.11 \%$. According to the report of ENR2017, the turnover of Chinese enterprises entering the top ENR250 is 95.16\% in Asia, Africa and Latin America (including the Middle East). The projects surveyed by the questionnaire are very consistent with the industry distribution of Chinese Contractors overseas business.

In terms of the type of industry in which the project is located, as shown in Figure 4 the overseas projects of Chinese contractors are mainly concentrated in the fields of housing construction engineering $34.52 \%$, transportation

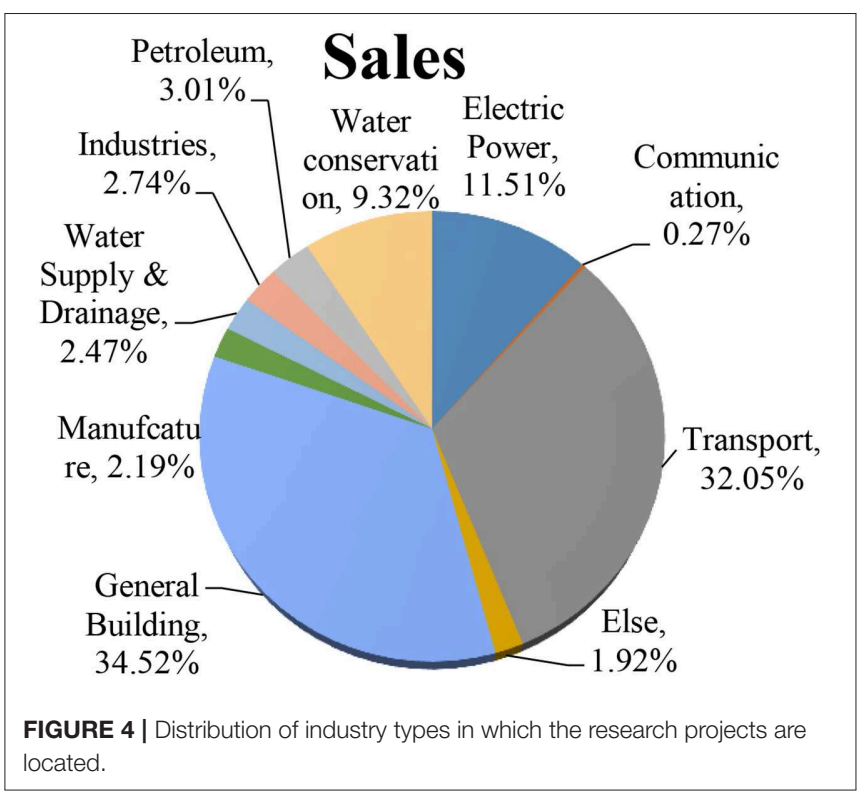

engineering $32.05 \%$, electric power engineering $11.51 \%$ and water conservancy and hydropower engineering 9.32\%, which account for $87.40 \%$. According to the ENR2017 report, the turnover of the top 250 enterprises in these four industries is $90.05 \%$. The survey items are basically consistent with the industry distribution of Chinese contractors. In addition, it is also slightly involved in communications, water supply and drainage engineering, industrial engineering, petroleum engineering and manufacturing engineering.

\section{PERFORMANCE OF COMPREHENSIVE ADAPTABILITY OF CHINESE CONTRACTORS FROM THE PERSPECTIVE OF POLITICAL RISK}

The international project contracting environment is different from that in China. To be able to operate continuously, the contractor must be able to adapt to the operating environment of the host country. Policy relating to national governments, including good relations with host countries (Al Khattab et al., 2007), advantageous treaties with a host government (Bing et al., 1999). The internal function of countries and the host country plays a crucial role in foreign construction operations (Yaprak and Sheldon, 1984). The high degree of localization of enterprises can weaken the identity and image of "foreigners" of enterprises, help enterprises better integrate into the local society and economy, and reduce the political risks they face. As shown in Figure 5, 9.49\% of Chinese contractors have localization of suppliers or subcontractors, $69.92 \%$ of Chinese contractors have localization of human resources, $77.24 \%$ of Chinese contractors have localization of operation and management, $34.69 \%$ of Chinese contractors have established subsidiaries or branches in the host country, and $36.04 \%$ of Chinese 
contractors have contracted business through joint ventures with local enterprises.

ICEs, which are expected to have less experience in the host country market, will have to compensate local partners for their absence of education about the local market (Johanson and Vahlne, 1990). Local partners can use the following options which gives benefits to ICEs: (1) access to the main construction market by lowering barriers to entry (Sui Pheng and Hongbin, 2003), (2) acquiring justification under institutional pressure (Chan and Makino, 2007), and (3) mitigating the image of Internationals (Ashley and Bonner, 1987). This reduces the probability of negative micro-economic results (Howell and Chaddick, 1994). Contractors with an adaptive organizational culture and a higher degree of participation and contribution to the local economy will receive more moral and social support. Contractors who try to accept, abide by the local social codes of conduct and fulfill their social responsibilities, and their space-time scope of survival will expand. The comprehensive adaptability of the contractor will enable the contractor to obtain more business opportunities and sustained operation. Energy groups can influence the performance of foreign construction projects as follows: (1) impact on decision makers; (2) Shaping the political and social environment; (3) Interference with activities (e.g., additional administrative checks). For example, trade unions play a more important role in the political economy of the country, often in joint and coordinated actions of the opposition with employees (Jauch, 2011). In terms of contribution to the local economy, as shown in Figure 6. 41.32\% of Chinese contractors contributed a lot to the local economy, promoted the local economic development, and contributed a lot of tax or employment positions; $29.75 \%$ of Chinese contractors contributed a little to the local economy, contributed a little to the local economic development, and created a small number of tax or employment positions; $27.27 \%$ of Chinese contractors had no special characteristics to the local economy. Other impacts: only $1.38 \%$ of Chinese contractors have a slight negative impact on the local economy, while $0.28 \%$ of Chinese contractors have a relatively obvious negative impact on the local economy because of their own entry leading to the crowding out of local enterprises, distorting the regional economic structure, resulting in unequal income distribution.

\section{COMMON POLITICAL RISKS OF OVERSEAS ENGINEERING PROJECTS BY CHINESE CONTRACTORS}

Governments in developing countries have picked up many issues, including the financial crisis, political risk, upcoming elections and reforms that may threaten the strength and

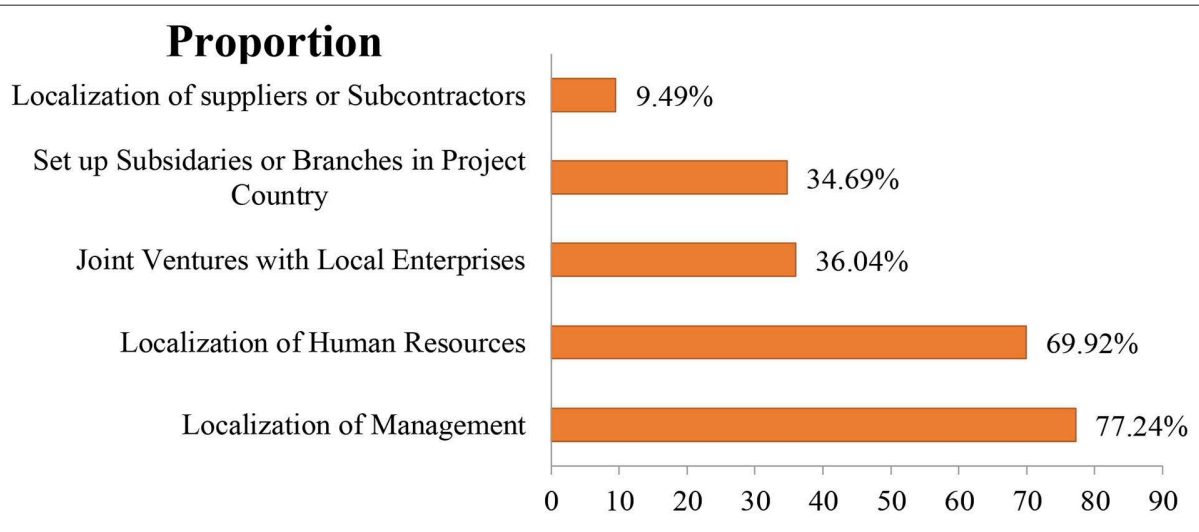

FIGURE 5 | Localization of Chinese contractors.

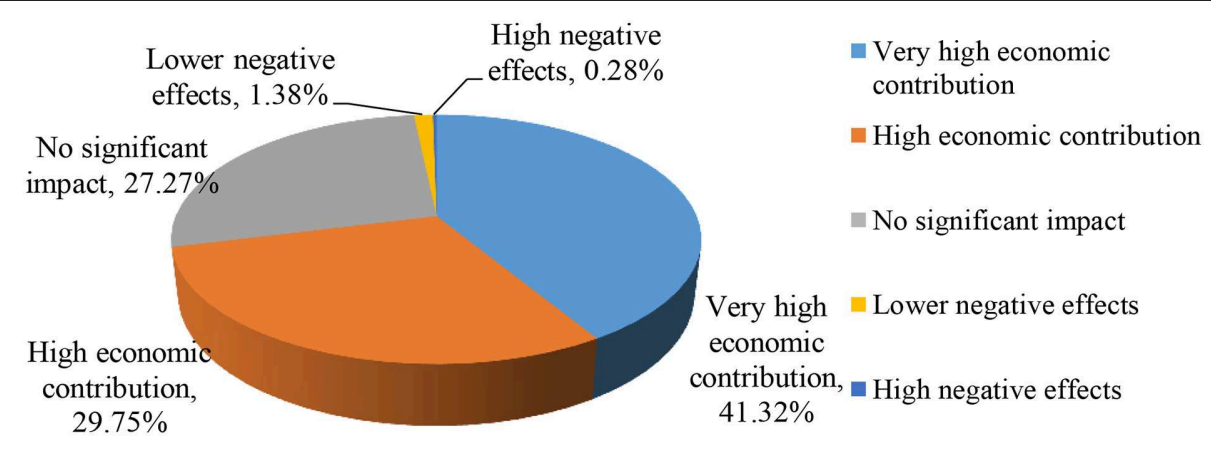

FIGURE 6 | The contribution of Chinese contractors to the local economy. 
permanency of government (Ling and Hoi, 2006). As host countries are part of an interconnected international and global system, state permanency is often affected by international conditions (Howell and Chaddick, 1994; Sachs et al., 2007), shattered political structures (Hastak and Shaked, 2000), leadership battles (Yaprak and Sheldon, 1984), and gap in public activity (Simon, 1984), previous investigations were also considered. A total of 324 respondents made it clear that they encountered political risks during the implementation of the project, as shown in Figure 7. The main types of political risks faced by Chinese contractors in overseas business are currency exchange risk, changes in legal policies, corruption, difficulty in approval, conflict or war, breach of contract by partners, breach of contract by host government, political violence, terrorism, industry restrictions, ethnic, and religious tensions, trade union protests and protests by environmental protection organizations (Oetzel, 2005). It is assumed that the size of the subordinate should be more important than the total size of the company to discover the political risk of the company (Alon and Herbert, 2009) and the number of variables in the enterprise that affect the company's micro-economic risks.

\section{Currency Exchange Risk}

Among them, currency exchange risk occurs most frequently. More than half of the projects surveyed have encountered currency exchange risk to some extent. On the one hand, exchange rate fluctuation is a common phenomenon. When the exchange rate of foreign currency to RMB decreases, the contractor's profit will decrease and suffer a certain degree of loss. On the other hand, in order to protect the interests of domestic enterprises, some countries, such as Singapore in Southeast Asia, often adopt foreign exchange control and other means to restrict the transfer of funds.

\section{Changes in Law and Policy}

The second most frequent occurrence was the change of law and policy in the project location, with $32.72 \%$ of the projects encountering such political risks. The change of law and policy may lead to the rise of prices and the increase of project cost. It may also lead to the change or invalidation of contract or the change of various approval procedures, thus increasing the operating cost of contractors and bringing losses to contractors. The reasons for the laws, regulations and policy changes of the host country are the usual government reforms and change of government, the change of the regime and the wishful thinking of the leaders. In areas where regimes are unstable, such as Central Asia, North Africa and the Caribbean, special attention needs to be paid to this.

\section{Corruption}

Corruption is also a common political risk for Chinese contractors when they operate projects. Corruption does not necessarily bring huge obstacles to the project, but in the process of political rent-seeking, Chinese contractors will inevitably increase the operating costs of enterprises and increase the uncertainty of the project. Generally speaking, corruption is closely related to the effectiveness of government and the improvement of legal system. At present, government corruption is more serious in Southeast Asia, Central Asia, Africa and South Asia.

\section{Difficulty of Examination and Approval}

Chinese contractors often encounter difficulties in examining and approving in the host country, including too long of an examination and approval cycle, harsh examination and approval conditions, too high examination and approval fees, and failure to pass the examination and approval. Administrative approval

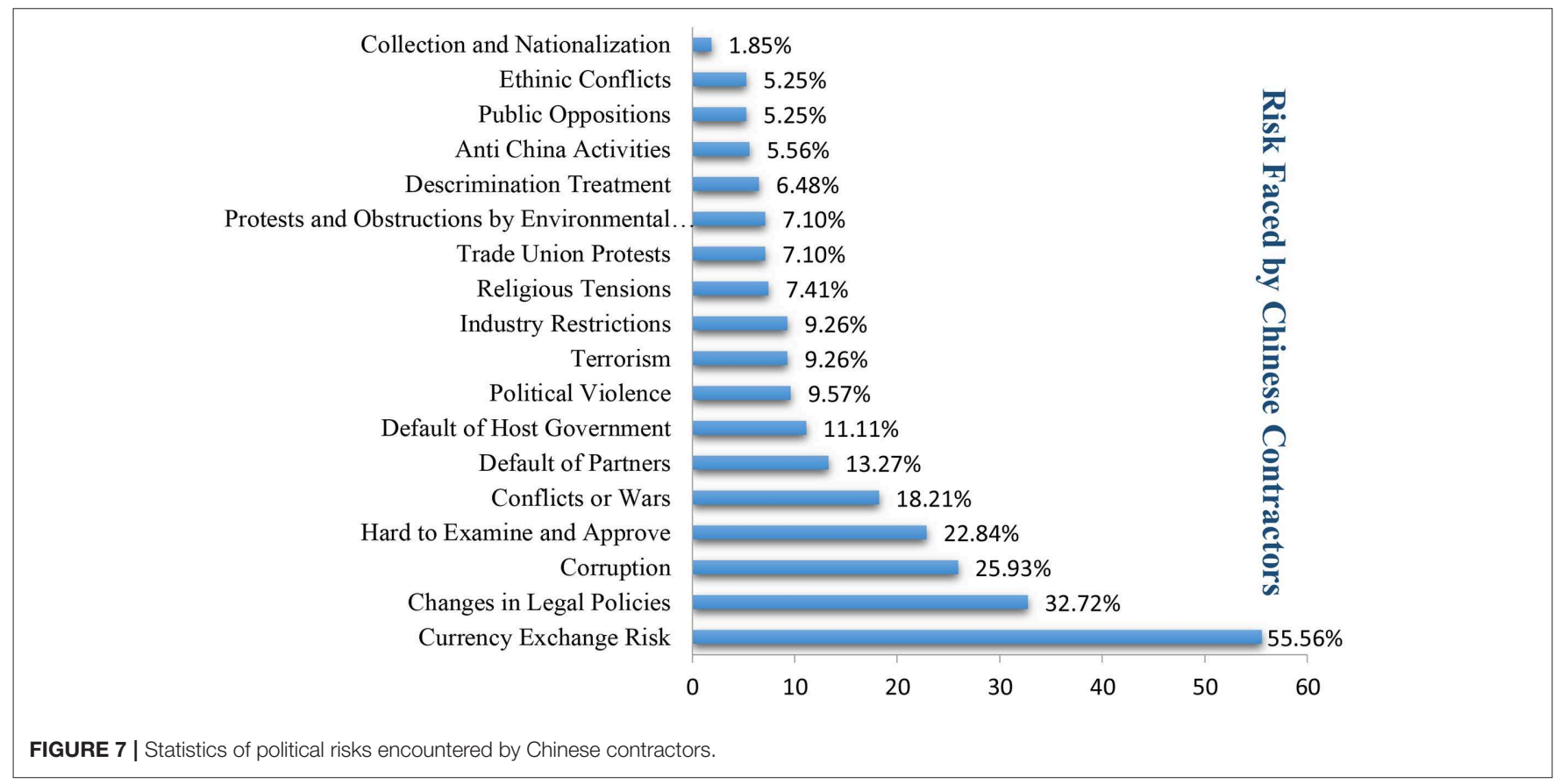


is often one of the main means by which the host government controls the market. On the one hand, due to the contractor's own improper behavior, some procedures do not meet the relevant requirements of the government in the implementation process. On the other hand, it may be due to the host government or the industry environment, such as bureaucracy, low maturity of the construction industry and so on.

\section{Conflict or War}

$18.21 \%$ of Chinese contractors have experienced conflicts or war incidents. Conflicts may be internal conflicts within the host country, including regional conflicts, conflicts between different factions, such as conflicts between the northern part of Myanmar and the central government, or conflicts between the countries. When the conflict rises, war will break out, such as the Iran-Iraq war in the Middle East, the war in Afghanistan and the war in Libya in Africa. Conflicts and wars will not only affect the normal progress of engineering projects, but also pose a huge threat to the personal safety of Chinese contractors, which will lead to the risk of destruction, loss, seizure or detention of project property or personnel of Chinese enterprises. Areas with high probability of conflict and war include North Africa, Central Africa, the Middle East, Southeast Asia and the Balkan Peninsula.

\section{POLITICAL RISK PROCESS IN INTERNATIONAL ENGINEERING PROJECTS}

\section{Formation of Political Risks in Traditional Risk Theory}

Risk is characterized as a result of the severity of the potential consequences of a risk event and the occurrence of likelihood, but the characteristics of the affected body (e.g., the engineering design system) and the dynamic effect of the affected organism are ignored or underestimated. Risks can be understood as overlapping external threats and inherent vulnerabilities.

Take, for example, the Mizon Myanmar hydroelectric project to analyze the formation of its political risks. The Misong hydroelectric power plant, a Chinese construction plant worth \$3.6 billion in Myanmar's Kachin Mountains, began construction in December 2009 and was originally scheduled to be completed in 2017, but was halted by the Burmese government in September 2011, causing billions of dollars in unspent damage to China. Myanmar is going through a political and social transition, while the Obama administration has implemented a strategy to rebalance the Asia-Pacific region, which lifted longstanding economic sanctions against Myanmar (international Environmental impacts). At the same time, anti-Chinese sentiment has increased among the Burmese public as a result of the intervention and exclusion of outside forces such as the United States, Japan and India, as well as China's antipathy toward supporting the old Burma regime. At the same time, the project itself has a number of vulnerabilities, such as the lack of transparency of the project, the presence of EIA problems; the implementation of the project was against the public. In addition, the project was influenced by the armed conflict in the northern region of Myanmar, and the Mizonga hydroelectric power plant was suspended due to various factors. In some cases, greater political risk depends on the relationship between home and host countries, and separate industries have distinguishing characteristics (Ashley and Bonner, 1987; Deng and Low, 2013).

\section{Political Risk}

Empirical education can only be learned from own experience, and own experience is more prevalent and necessary than objective knowledge (Johanson and Vahlne, 1990). The Global Risk Assessment Report classifies global risks into two categories: "Creep Risk" and "Acute Risk." The two manifestations of risk are different; the risk of creep is in a stable state in a slow, continuous, gradual state, and the risk of dramatic changes in crisis conditions to show a sharp, intermittent, emergency condition. In the process of forming political risks, the gradual normality and disnaturous nature of the drama intersected and interacted with each other. Its evolutionary path is the process of alternating a relatively long period of equilibrium and mutagenic phase of a relatively short period.

The theory of intermittent equilibrium stems from the theory of evolutionary biology, which believes that evolution is an alternation of mutation and gradient, emphasizing the unevenness of the evolutionary process. The intermittent balance theory uses the "threshold event" to explain the timing of the change. Some key developments may lead to a transition period that will lead to a political socio-economic transition.

The suddenness and certainty of political risk make it difficult to accurately predict and control it. The theory of intermittent equilibrium can be built to build a theoretical basis, describing and explaining both the degree of the normal and abnormal variability in the process of political risk formation, as shown in Figure 8.

The ripeness of the host country's construction sector implies the extent to which transparent information is provided and market practices are assimilate (Deng et al., $2014 a, b)$. International contractors performing in countries with limited sovereignty of trade and may be affected by more active interference by host Governments (Agarwal and Feils, 2007) before entering the host country. In general, the host country's political, social and economic system is in a state of sustainable development and the system is selfregulating. This balance is determined by the host nation's political system, social values, social structure, economic situation and international environment. But under certain circumstances, this balance can be disturbed, leading to a mutation. The duration of the mutation phase is usually shorter than at the equilibrium stage. In accordance with the process of transferring political risk, it can be divided into four periods:

(1) Brewing period: under the trigger of a threshold event, potential factors of instability in the political, social and economic environment of the host country are caused, intensifying the process of relevant political and social events, making political risk and thus produce energy risk, and the "trump effect" makes the energy risk begin to spread. 


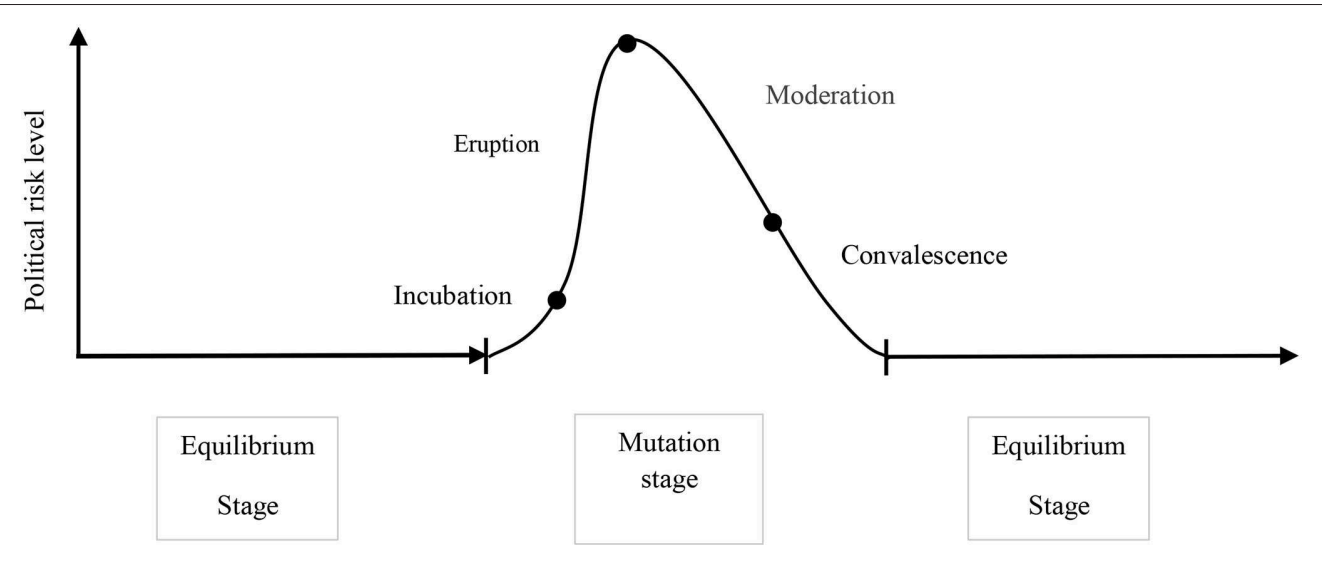

FIGURE 8 | Intermittent-balanced behavior of political risk.

(2) Outbreak period: political and social events caused by several factors which quickly accumulate the energy of risk and begin to spread. The "Information Spiral" allows the energy of risk to spread non-linear, interconnected and connecting in time and space at a higher speed, diversified channel, and in a greater range of time and space. When energy exceeds the tolerance of the host country's political and social systems, it will upset the original balance. This, in turn, affects industries, businesses and projects, which dramatically changes the operating environment of the project. The period of brewing and flare-ups is a process of positive feedback, positive feedback strengthens the momentum of political, social and economic changes, overcomes inertia to break the original balance.

(3) Mitigation period: As part of a series of risk mitigation measures, the energy of risk is gradually released and dissipated. In space, the scale of risk events is suppressed, and over time, the impact of risk events gradually decreases.

(4) Recovery period: With the further resolution of the crisis, as well as the adaptation of political, social and economic systems, the political, economic and social order from disorder to order, gradually returned to the original stage of equilibrium or entered to a new stage of equilibrium.

The period of weakening and the period of recovery is a process of negative feedback, and the adaptive ability and ability to selfheal the political, social and economic system of the host country, in the face of energy risk force, causes the system to stabilize and thus achieve equilibrium.

The duration of each period varies, and in general the outbreak period is relatively short and the recovery period is longer. The duration will vary depending on the stability of the host country's political and social systems and the type of political risk.

During the mutation phase, the initial risk of creep may also develop into a sharp risk, such as a change in policy/law. Most policies/laws are stagnant, stable and in a state of gradual change in the long term. In a balancing act, policy/legislative changes go through a full set of procedures, starting with submission, review and release, which can sometimes be extremely long-lasting in a democratic and legal society. For this kind of political risk, appropriate precautions can be predicted and taken. However, at the mutation stage, this procedure and time will be reduced accordingly, and the policy/law will show a significant nonlinear transition. Basic engineering technology can improve the company's market power (Zhuang et al., 1998) and foreign competitiveness (Lu et al., 2008).

Sources of combative advantage, such as scientific alteration, tactical association (Hitt et al., 2000), organizational customs (Fiol, 1991), human wealth (Wright et al., 1994), and transfer of knowledge (Argote and Ingram, 2000) from previous investigations were also considered. International companies with big market supremacy may use unfavorable reactions in the host country (De la Torre and Neckar, 1988) and have more strength in the market to improve its dealing position. Corporations in local markets can reduce their market strength and increase their micro-political risk (Grosse, 1996; Alon and Herbert, 2009). The relative bargaining power between the contractor and the host country determines the level of political risk. The higher the degree of internalization and decentralization of contractors the higher their dealing strength comparative to host government. For example, for a large multinational enterprise, the host government's intervention measures will bear tremendous pressure. More attention should be drawn to the analysis of the management of political risks, not only at the national or industrial level (Frynas and Mellahi, 2003).

The evolution of the political risk of the Sino-Thai railway is analyzed by the theory of intermittent equilibrium. China and Thailand cooperated on a high-speed rail project, totalling 873 kilometers and about 13 billion U.S. dollars, has involved three governments in Thailand, after more than 20 rounds of negotiations, and the project is in progress in different twists. Figure 9 is a map of the political risks of the Sino-Thai highspeed railway. Due to political instability in Thailand, the frequent occurrence of intermittent periods, the balance period is relatively short, reflecting a strong policy cessation. 


\begin{tabular}{|c|c|c|c|c|c|}
\hline 2010.09 & 2013.10 & 2014.12 & 2016.03 & 2017.07 & 2018 \\
\hline $\begin{array}{l}\text { Thai Cabinet } \\
\text { approves the } \\
\text { Negotiation } \\
\text { Framework of } \\
\text { China-Thailand } \\
\text { Cooperation High- } \\
\text { speed Rail }\end{array}$ & $\begin{array}{l}\text { China and } \\
\text { Thailand } \\
\text { signed an } \\
\text { agreement to } \\
\text { exchange } \\
\text { rice for high- } \\
\text { speed rail }\end{array}$ & $\begin{array}{l}\text { China and } \\
\text { Thailand } \\
\text { Signed } \\
\text { Memorandum } \\
\text { of } \\
\text { Understanding } \\
\text { on China- } \\
\text { Thailand }\end{array}$ & $\begin{array}{l}\text { Thailand } \\
\text { decided to } \\
\text { build its } \\
\text { own high- } \\
\text { speed } \\
\text { railway }\end{array}$ & $\begin{array}{l}\text { China and } \\
\text { Thailand to } \\
\text { restart the high- } \\
\text { speed rail } \\
\text { construction } \\
\text { program }\end{array}$ & $\begin{array}{l}\text { Variables Still } \\
\text { Exist in } \\
\text { China- } \\
\text { Thailand } \\
\text { High-speed } \\
\text { Rail... }\end{array}$ \\
\hline
\end{tabular}

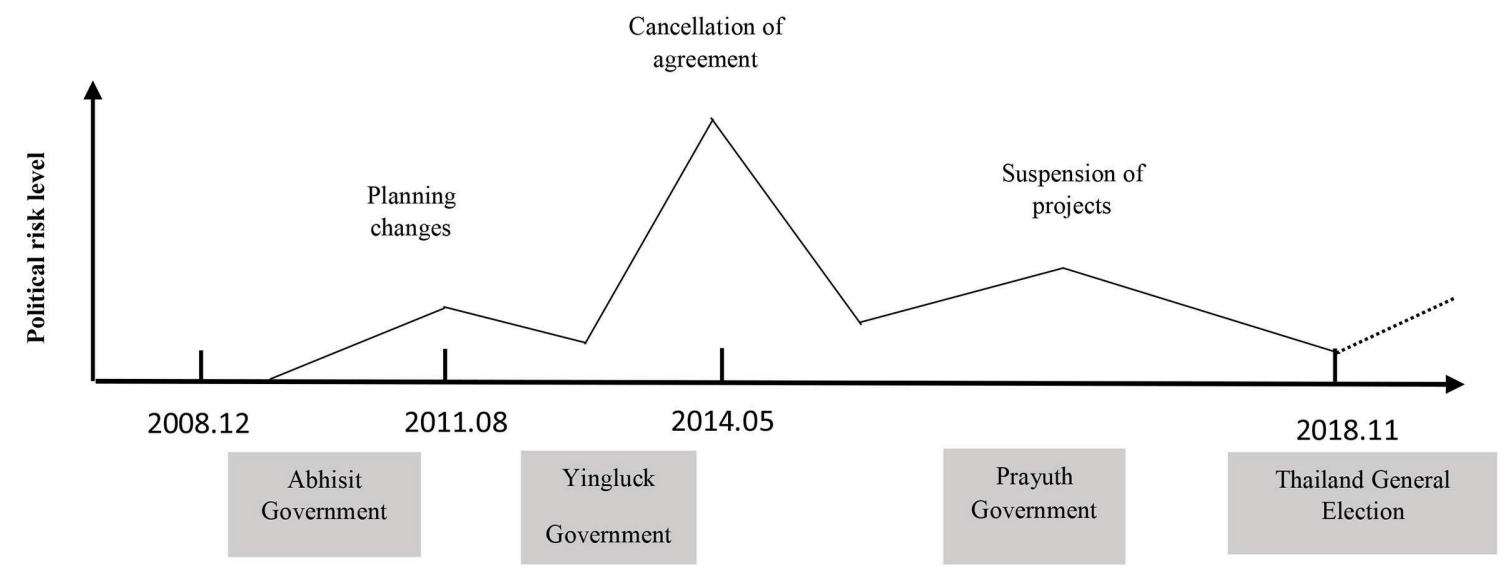

FIGURE 9 | Map of the evolution of political risks on China-Tai High-Speed Railroad.

\section{A Key Path to Political Risk for International Engineering Projects}

There are many types of political risks, and their influences are numerous and complex. Even a particular type of political risk is determined by a combination of factors such as the international environment, internal affairs and foreign affairs of the host country, social issues, racism, as well as the nationality and behavior of the contractor, social and environmental impact of the project. These factors are sometimes cause-and-effect with each other, and the triggering of some threshold events determines the speed and manner of the political process of risk. In different regions, the path of political risk formation is not the same, showing different ways of evolution. But in essence, the evolutionary path still has regular rules to follow, showing some commonalities.

Most foreign contractors found that they could not change it frequently (Ling and Low, 2007). With the help of the analytical "event-analysis" regime of more than 100 collected cases, we can understand the process of forming political risk from specific events. At the same time, combined with the Bayes network, we explore the law of political risk, and refine the key path with high frequency and versatility. Offenses or violations committed by employees who cause accidents (Mohamed, 2002). Management of construction facilities with protection systems (e.g., security personnel, observing devices and signaling appliances) can contribute to the separation of violation, terrorist attacks and armed conflict (Chang et al., 2017).
The Las-Vegas Los Angeles high-speed rail project, which Private American Railway Company Western Express has terminated its cooperation with China Railway Stoic, is a breach of contract on the part of the partner, which is not only by a commercial act, but also by a political motive. At first glance, the biggest obstacle to high-speed rail cooperation between China and the United States is that the "U.S. government requires high-speed trains to be produced in the U.S," but the main reason is sitting because of partisan bickering between Democrats and Republicans, political games between the federal and state governments, and the political direction of China-U.S. relations, making it difficult for him to approve the projects (Table 2).

\section{CONCLUSIONS}

Political risk analysis can be carried out in international construction projects, but the main purpose of the research is limited capabilities of Chinese contractors in the international market. It is important that the ICEs correctly understand the issues of political risk. This research presents the results of the analysis of political risks of international construction projects of Chinese contractors.

Despite the achievement of the goal, there are inevitably some limitations. First, we collected data only through surveys, limiting the validity of the responses gathered. However, we feel the sample size was still sufficient for a very large and exploratory analysis. Nevertheless, the research contributes to 
TABLE 2 | Keyways to shape typical political risks in international engineering.

\begin{tabular}{|c|c|c|c|}
\hline No & $\begin{array}{l}\text { Types of political } \\
\text { risk }\end{array}$ & Critical path & High-risk areas \\
\hline 1 & $\begin{array}{l}\text { Currency } \\
\text { exchange risk }\end{array}$ & $\begin{array}{l}\text { International financial } \\
\text { environment, exchange rate } \\
\text { fluctuations, foreign exchange } \\
\text { policy adjustments }\end{array}$ & $\begin{array}{l}\text { Africa, South } \\
\text { America, } \\
\text { Southeast Asia }\end{array}$ \\
\hline 2 & $\begin{array}{l}\text { Changes in legal } \\
\text { policy }\end{array}$ & $\begin{array}{l}\text { Local Protectionism, Government } \\
\text { Change/Change - Government } \\
\text { Intervention }\end{array}$ & $\begin{array}{l}\text { Africa, Central } \\
\text { America, South } \\
\text { America, South } \\
\text { East Asia }\end{array}$ \\
\hline 3 & Corruption & $\begin{array}{l}\text { The rule of law is not perfect, the } \\
\text { culture of social defeat, the } \\
\text { corruption of power }\end{array}$ & $\begin{array}{l}\text { Southeast Asia, } \\
\text { Africa, South } \\
\text { America }\end{array}$ \\
\hline 4 & Difficult to approve & $\begin{array}{l}\text { Poor government governance, } \\
\text { industry irregularities, lengthy } \\
\text { approval process }\end{array}$ & $\begin{array}{l}\text { Central Asia, } \\
\text { South-East Asia, } \\
\text { Africa }\end{array}$ \\
\hline 5 & Conflict or War & $\begin{array}{l}\text { International political environment, } \\
\text { conflict of interest, territorial } \\
\text { disputes, war }\end{array}$ & $\begin{array}{l}\text { Middle East, } \\
\text { Africa, South Asia }\end{array}$ \\
\hline 6 & Partner default & $\begin{array}{l}\text { Factional conflicts, government } \\
\text { intervention, difficulty in obtaining } \\
\text { government permission }\end{array}$ & $\begin{array}{l}\text { North America, } \\
\text { Southeast, South } \\
\text { America }\end{array}$ \\
\hline 7 & $\begin{array}{l}\text { Government } \\
\text { default }\end{array}$ & $\begin{array}{l}\text { Social contradictions, social } \\
\text { instability, political instability, } \\
\text { government default }\end{array}$ & $\begin{array}{l}\text { South East Asia, } \\
\text { Central America, } \\
\text { South America, } \\
\text { Africa }\end{array}$ \\
\hline 8 & Political violence & $\begin{array}{l}\text { Interests Divide, Factional } \\
\text { Conflict, Social Unrest, Regime } \\
\text { Change }\end{array}$ & $\begin{array}{l}\text { Africa, Southeast } \\
\text { Asia, South } \\
\text { America }\end{array}$ \\
\hline 9 & Terrorism & $\begin{array}{l}\text { Clash of Civilizations, Nationalism, } \\
\text { Terrorist Activities, War on Terror }\end{array}$ & $\begin{array}{l}\text { South Asia, Africa, } \\
\text { Middle East }\end{array}$ \\
\hline 10 & $\begin{array}{l}\text { Industry } \\
\text { restrictions }\end{array}$ & $\begin{array}{l}\text { Nationalities/Racism, Exclusion of } \\
\text { China, Trade Protectionism }\end{array}$ & $\begin{array}{l}\text { North America, } \\
\text { Western Europe, } \\
\text { Southeast Asia }\end{array}$ \\
\hline
\end{tabular}

literatures on political risks. In the context of consultations of the international construction industry with international contractors, more attention is paid to these important variables

\section{REFERENCES}

Agarwal, J., and Feils, D. (2007). Political risk and the internationalization of firms: an empirical study of Canadian-based export and FDI firms. Can. J. Administr. Sci. 24, 165-181. doi: 10.1002/cjas.26

Al Khattab, A., Anchor, J., Davies, E. (2007). Managerial perceptions of political risk in international projects. Int. J. Proj. Manag. 25, 734-743. doi: 10.1016/j.ijproman.2007.03.006

Alon, I., and Herbert, T. T. (2009). A stranger in a strange land: micro political risk and the multinational firm. Business Horizon. 52, 127-137. doi: 10.1016/j.bushor.2008.09.004

Alon, I., and Martin, M. A. (1998). Political Risk Assessment1. Multinational Business Review.

Argote, L., and Ingram, P. (2000). Knowledge transfer: a basis for competitive advantage in firms. Org. Behav. Hum. Dec. Proc. 82, 150-169. doi: 10.1006/obhd.2000.2893

Ashley, D. B., and Bonner, J. J. (1987). Political risks in international construction. J. Constr. Eng. Manag. 113, 447-467. doi: 10.1061/(ASCE)0733-9364(1987)113:3(447)

Bing, L., Lee-Kong, T., Fan, W. W., Chew, Da-S. (1999). Risk management in international construction joint ventures. J. Construct. Eng. and the implementation of project management to eliminate political risk.

The survey results also help ICEs to consider choosing the right project in the context of political risk. Although all research specialists were Chinese international contractors, it was believed that the results of the study could serve as a useful basis for all ICEs, regardless of their country of origin. Some urgent studies deserve further investigation to check the viability of other international contractors in the construction industry.

The specificity of specific projects should also be taken into account in the context of political risk management practices (Deng et al., 2014b), however, despite these limitations, the study presents a new model project on the assessment of political risks in international construction. The discovered risks and chances, as well as existing policies, contributed to the development of the international community in the Central Asian market. Future research options prevail, and can explore the external environment and the features of international design projects between interactions. Measures should be taken to revise the mechanisms for formatting political risks of specific projects in different contexts.

\section{DATA AVAILABILITY}

The datasets generated for this study are available on request to the corresponding author.

\section{AUTHOR CONTRIBUTIONS}

SU and XD are responsible for everything including the data collection, the data analysis, the design, and the development of research. The draft manuscript was done by SU. XD and TC provided review and comments. All the authors were engaged in the final manuscript preparation and agreed to the publication of this paper.

Manag. 125, 277-284. doi: 10.1061/(ASCE)0733-9364(1999)125: 4(277)

Chan, C. M., and Makino, S. (2007). Legitimacy and multi-level institutional environments: Implications for foreign subsidiary ownership structure. J. Int. Bus. Stud. 38, 621-638. doi: 10.1057/palgrave.jibs.8400283

Chang, T., Deng, X., Zuo, J., Yuan, J. (2017). Political risks in Central Asian countries: factors and strategies. J. Manag. Eng. 34:04017059. doi: 10.1061/(ASCE)ME.1943-5479.0000588

Chen, C. (2008). Entry mode selection for international construction markets: the influence of host country related factors. Construct. Manag. Econ. 26, 303-314. doi: 10.1080/01446190701882382

De la Torre, J., and Neckar, D. H. (1988). Forecasting political risks for international operations. Int. J. Forecast. 4, 221-241. doi: 10.1016/0169-2070(88)90079-9

De Mortanges, C. P., and Allers, V. (1996). Political risk assessment: theory and the experience of Dutch firms. Inter. Bus. Rev. 5, 303-318. doi: 10.1016/0969-5931(96)00012-1

Deng, X., and Low, S. P. (2013). Exploring critical variables that affect political risk level in international construction projects: case study from Chinese contractors. J. Profession. Issues Eng. Edu. Pract. 140:04013002. doi: 10.1061/(ASCE)EI.1943-5541.0000174 
Deng, X., Low, S. P., Li, Q., Zhoa, X. (2014a). Developing competitive advantages in political risk management for international construction enterprises. J. Construct. Eng. Manag. 140, 04014040. doi: 10.1061/(ASCE)CO.1943-7862.0000836

Deng, X., Pheng, L. S., Zhoa, X. (2014b). Project system vulnerability to political risks in international construction projects: the case of Chinese contractors. Project Manag. J. 45, 20-33. doi: 10.1002/pmj.21397

Denisova-Schmidt, E., Ledeneva, A., and Shekshnia, S. (2014). Anti-corruption strategies for businesses operating in Russia. Russian Analyt. Digest. 144, 5-8.

Fan, L. C., and Fox, P. W. (2009). Exploring factors for ethical decision making: Views from construction professionals. J. Profess. Issues Eng. Edu. Pract. 135, 60-69. doi: 10.1061/(ASCE)1052-3928(2009)135:2(60)

Farrell, H., and Knight, J. (2003). Trust, institutions, and institutional change: Industrial districts and the social capital hypothesis. Polit. Soc. 31, 537-566. doi: $10.1177 / 0032329203256954$

Fiol, C. M. (1991). Managing culture as a competitive resource: an identitybased view of sustainable competitive advantage. J. Manag. 17, 191-211. doi: $10.1177 / 014920639101700112$

Frynas, J. G., and Mellahi, K. (2003). Political risks as firm-specific (dis) advantages: evidence on transnational oil firms in Nigeria. Thunderbird Int. Bus. Rev. 45, 541-565. doi: 10.1002/tie.10090

Grosse, R. (1996). The bargaining relationship between foreign MNEs and host governments in Latin America. Int. Trade J. 10, 467-499. doi: $10.1080 / 08853909608523865$

Gunhan, S., and Arditi, D. (2005). International expansion decision for construction companies. J. Construct. Eng. Manag. 131, 928-937. doi: 10.1061/(ASCE)0733-9364(2005)131:8(928)

Han, S. H., Park, S. H., Kim, D. Y., Kim, H. (2007). Causes of bad profit in overseas construction projects. J. Construct. Eng. Manag. 133, 932-943. doi: 10.1061/(ASCE)0733-9364(2007)133:12(932)

Hastak, M., and Shaked, A. (2000). ICRAM-1: model for international construction risk assessment. J. Manag. Eng. 16, 59-69. doi: 10.1061/(ASCE)0742-597X(2000)16:1(59)

Henisz, W. J. (2000). The institutional environment for multinational investment. J. Law Econ. Organ. 16, 334-364. doi: 10.1093/jleo/16.2.334

Hitt, M. A., Dacin, T., Levitas, E., Arregle, J. L., Borza, A. (2000). Partner selection in emerging and developed market contexts: Resource-based and organizational learning perspectives. Acad. Manag. J. 43, 449-467. doi: $10.5465 / 1556404$

Howell, L. D., and Chaddick, B. (1994). Models of political risk for foreign investment and trade: an assessment of three approaches. Columbia J. World Bus. 29, 70-91. doi: 10.1016/0022-5428(94)90048-5

Iankova, E., and Katz, J. (2003). Strategies for political risk mediation by international firms in transition economies: the case of Bulgaria. J. World Bus. 38, 182-203. doi: 10.1016/S1090-9516(03)00018-X

Jauch, H. (2011). Chinese Investments in Africa: Twenty-First Century Colonialism? Los Angeles, CA: New Labor Forum, SAGE Publications Sage CA. doi: 10.4179/NLF.202.0000008

Johanson, J., and Vahlne, J. E. (1990). The mechanism of internationalisation. Int. Market. Rev. 7, 11-23. doi: 10.1108/02651339010137414

Keillor, B., Hauser, W., Griffin, A. (2009). The relationship between political risk, national culture and foreign direct investment as a market entry strategy: perspectives from US firms. Innovat. Market. 5, 48-54.

Kesternich, I., and Schnitzer, M. (2010). Who is afraid of political risk? multinational firms and their choice of capital structure. J. Int. Econ. 82, 208-218. doi: 10.1016/j.jinteco.2010.07.005

Kobrin, S. J. (1982). Managing Political Risk Assessment: Strategic Response to Environmental Change. Berkeley, CA: University of California Press.
Kobrin, S. J. (1987). Testing the bargaining hypothesis in the manufacturing sector in developing countries. Int. Org. 41, 609-638. doi: $10.1017 /$ S0020818300027624

Kuchins, A. C., Mankof, J., Kourmanova, A., Backes, O. (2015). Central Asia in a Reconnecting Eurasia: Uzbekistan's Evolving Foreign Economic and Security Interests. Lanham, MD: Rowman \& Littlefield.

Laruelle, M., and Peyrouse, S. (2015). Globalizing Central Asia: Geopolitics and the Challenges of Economic Development. New York, NY: Routledge.

Ling, F. Y., and Low, S. P. (2007). Legal risks faced by foreign architectural, engineering, and construction firms in China. J. Profession. Issues Eng. Edu. Pract. 133, 238-245. doi: 10.1061/(ASCE)1052-3928(2007)133:3(238)

Ling, F. Y. Y., and Hoi, L. (2006). Risks faced by Singapore firms when undertaking construction projects in India. Int. J. Proj. Manag. 24, 261-270. doi: 10.1016/j.ijproman.2005.11.003

Lu, W., Shen, L., Yam, M. C. (2008). Critical success factors for competitiveness of contractors: China study. J. Construct. Eng. Manag. 134, 972-982. doi: 10.1061/(ASCE)0733-9364(2008)134:12(972)

Mazhikeyev, A., Edwards, T. H., Rizov, M. (2015). Openness and isolation: the trade performance of the former Soviet Central Asian countries. Int. Bus. Rev 24, 935-947. doi: 10.1016/j.ibusrev.2015.03.001

Mohamed, S. (2002). Safety climate in construction site environments. J. Construct. Eng. Manag. 128, 375-384. doi: 10.1061/(ASCE)0733-9364(2002)128: $5(375)$

Oetzel, J. (2005). Smaller may be beautiful but is it more risky? Assessing and managing political and economic risk in Costa Rica. Int. Bus. Rev. 14, 765-790. doi: 10.1016/j.ibusrev.2005.09.002

Robock, S. H., and Simmonds, K. (1973). International business and multinational enterprises. Int. Execut. 15, 5-6. doi: 10.1002/tie.50601 50303

Sachs, T., Tiong, R. L. K., Wagner, D. (2007). The quantification and financial impact of political risk perceptions on infrastructure projects in Asia 80. J. Struct. Finance 13:80. doi: 10.3905/jsf.13.4.80

Simon, J. D. (1984). A theoretical perspective on political risk. J. Int. Bus. Stud. 15, 123-143. doi: 10.1057/palgrave.jibs.8490499

Sui Pheng, L., and Hongbin, J. (2003). Internationalization of Chinese construction enterprises. J. Construct. Eng. Manag. 129, 589-598. doi: 10.1061/(ASCE)0733-9364(2003)129:6(589)

Wright, P. M., McMahan, G. C., McWilliams, A. (1994). Human resources and sustained competitive advantage: a resource-based perspective. Int. J. Hum. Res. Manag. 5, 301-326. doi: 10.1080/09585199400000020

Xiaopeng, D., and Pheng, L. S. (2013). Understanding the critical variables affecting the level of political risks in international construction projects. KSCE J. Civil Eng. 17, 895-907. doi: 10.1007/s12205-013-0354-5

Yaprak, A., and Sheldon, K. T. (1984). Political risk management in multinational firms: an integrative approach. Manag. Deci. 22, 53-67. doi: 10.1108/eb001368

Zhuang, L., Ritchie, R., Zhang, Q. (1998). Managing business risks in China. Long Range Plann. 31, 606-614. doi: 10.1016/S0024-6301(98)80053-8

Conflict of Interest Statement: The authors declare that the research was conducted in the absence of any commercial or financial relationships that could be construed as a potential conflict of interest.

Copyright $(2019$ Ullah, Deng and Chang. This is an open-access article distributed under the terms of the Creative Commons Attribution License (CC BY). The use, distribution or reproduction in other forums is permitted, provided the original author(s) and the copyright owner(s) are credited and that the original publication in this journal is cited, in accordance with accepted academic practice. No use, distribution or reproduction is permitted which does not comply with these terms. 